\title{
Synthesis and structural characterizations of tris (hydroxymethyl) aminomethane complexes with group IIA metals
}

\author{
Lamia A. Albedair \\ Dept. of Chemistry, College of Science, \\ Princess Nourah Bint Abdulrahman University, \\ Riyadh 11671, Saudi Arabia \\ Corresponding author: lamiaalbedair@yahoo.com
}

\begin{abstract}
Herein, this article aimed to investigate the tendency of tris(hydroxymethyl) aminomethane (THAM) to form stable complexes with group IIA metals. Four new colorless solid complexes of group IIA metals [Ba(II), $\mathrm{Ca}$ (II), $\mathrm{Sr}(\mathrm{II})$, and $\mathrm{Mg}(\mathrm{II})]$ with THAM were prepared and well characterized. The chemical reactions between-group IIA metals and THAM were conducted by the stoichiometry of 2:1 (Ligand: Metal ion) at $65^{\circ} \mathrm{C}$ and $\mathrm{pH}$ of $\sim 8.5$. Under these conditions, the THAM molecule $\left(\mathrm{C}_{4} \mathrm{H}_{11} \mathrm{NO}_{3}\right)$ was deprotonated and converted to the $\left(\mathrm{C}_{4} \mathrm{H}_{10} \mathrm{NO}_{3}^{-} ; \mathrm{L}^{-}\right)$chelate with the metal ions. The structures of these complexes were suggested by UV-visible, IR, Raman and ${ }^{1} \mathrm{H}$ NMR spectroscopies and other physicochemical and analytical methods (elemental analysis, thermogravimetry, and SEM). The results shows that the general composition of the complexes obtained with $\mathrm{Ba}$ (II), $\mathrm{Ca}$ (II), $\mathrm{Sr}$ (II), and $\mathrm{Mg}$ (II) ions are $\left[\mathrm{BaL}_{2}\left(\mathrm{H}_{2} \mathrm{O}\right)_{2}\right], \quad\left[\mathrm{CaL}_{2}\left(\mathrm{H}_{2} \mathrm{O}\right)_{2}\right] \cdot 2 \mathrm{H}_{2} \mathrm{O}, \quad\left[\mathrm{SrL}_{2}\left(\mathrm{H}_{2} \mathrm{O}\right)_{2}\right]$, and $\left[\mathrm{MgL}_{2}\left(\mathrm{H}_{2} \mathrm{O}\right)_{2}\right] \cdot 4 \mathrm{H}_{2} \mathrm{O}$, respectively, and in all complexes, the geometry was octahedral.
\end{abstract}

Keywords: Group IIA metals; spectral analysis; thermogravimetry; tris(hydroxymethyl) aminomethane.

\section{Introduction}

The structure of tris(hydroxymethyl)aminomethane (THAM) which is shown in Figure 1, is a small organic molecule that exists as a colorless crystalline powder with a melting point of $175-176^{\circ} \mathrm{C}$ and chemical formula $\left(\mathrm{C}_{4} \mathrm{H}_{11} \mathrm{NO}_{3}\right)(121.14 \mathrm{~g} / \mathrm{mol})$. THAM has a several synonyms, such as Tris, Tris base, Tris buffer, Trisaminol, Trometamol, THAM, and Trizma. THAM is structurally related to the amino alcohol group that consists of one amino group and three hydroxyl groups. It is considered an alkalizing agent that is preferred over $\mathrm{Na}_{2} \mathrm{CO}_{3}$. THAM has several applications in physiology, biology, medicine, and biochemistry [Bubb et al., 1995]. It is widely used biochemically as a buffer for several biochemical processes [Brignac \& Mo, 1975; Hayashi et al., 1981; Lundblad \& Macdonald, 2010; Albishri \& Marwani, 2016; El-Dissouky et al., 2020] and used clinically to reverse acidosis [Murakami et al., 2016; Kallet et al., 2000; Weber et al., 2000; Nahas et al., 1998]. Several THAM Schiff base derivatives showed a broad spectrum of biological activity, like anti-inflammatory, antifungal, antihistamine, anticancer, and anti-tumor effects. Several works reported the crystal structures of some THAM Schiff base ligands [Tatar et al., 2005; Odabasoglu et al., 2003; Asgedom et al., 1995]. 
The coordination chemistry of metal-based and metallodrug compounds is attracting considerable interest from pharmacists and chemists because these compounds may have a significant application in many important fields such as biology, pharmacology, and medicine to catalysis and material sciences and they can be used to design more biologically active drugs [Tella et al., 2019; Mohammed et al., 2014; Alessio, 2011; Tarafder et al., 2001; Vakili et al., 2021; Ali et al., 2021]. Several metal-based compounds have been proven to possess potential biological activities, like antibacterial, antifungal, antiviral, and anticancer activities. For example, several platinum-based compounds have utility in cancer therapy for treating several solid tumors, like bladder, ovarian, and testicular cancers [Khan et al., 2019; Sayadi et al., 2019; Cao et al., 2017; Tavares et al., 2017; Singh et al., 2016; Saleem et al., 2013; Trudu et al., 2015; Crisóstomo-Lucas et al., 2015; Pagoto et al., 2015; Muhammad \& Guo, 2014; Mjos \& Orvig 2014; Abdel-Rahman et al., 2014; Guidi et al., 2013; Abdel Ghani \& Mansour, 2011; Dabrowiak, 2017; Hambley, 2001; Köpf-Maier, 1994]. However, drug resistance and adverse side effects have limited the effectiveness and applications of several metal-based drugs [Qin et al., 2019; Dominelli et al., 2018; Meng et al., 2016; Hu et al., 2016; Lai et al., 2015; Dasari \& Tchounwou 2014; Galluzzi et al., 2012; Maheswari et al., 2008]. Furthermore, the occurrence and fate of antibiotic residues in the environment and the extensive overuse of antibiotics caused, an increased bacterial drug resistance [Howse et al., 2019; Deng et al., 2019; Dai et al., 2018; Walsh et al., 2016]. The Global Review of Antimicrobial Resistance issued by the WHO in 2016 reported that drug-resistant infections will cause the death of 700,000 people every year [WHO, 2016]. Therefore, there is an urgent need to discover and design new metal-based compounds with the potential efficiency to overcome drug resistance and extend over the antimicrobial/anticancer spectrum with fewer side effects.

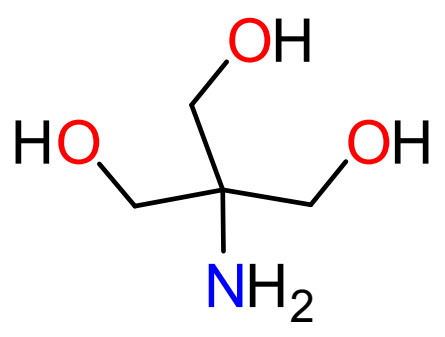

Fig. 1. Molecular structure of THAM.

Synthesizing new metal complexes may play an interesting role in the development of effective metal-based drugs. Herein, we reported the synthesis and characterization of four new products of THAM with the metal ions of Group II [Ba(II), $\mathrm{Ca}(\mathrm{II}), \mathrm{Sr}(\mathrm{II})$, and $\mathrm{Mg}$ (II)] to throw more light and provides new insights on the complexation tendency and chelation behavior of THAM towards metals. The work is separated into two sections:

\section{(i) Synthesis of the THAM complexes:}

The complexes were prepared by reacting THAM with the $\mathrm{Ba}(\mathrm{II}), \mathrm{Ca}(\mathrm{II}), \mathrm{Sr}(\mathrm{II})$ and $\mathrm{Mg}(\mathrm{II})$ ions in $\mathrm{MeOH}: \mathrm{H}_{2} \mathrm{O}$ solvent with a 1:2 (Metal: Ligand) ratio at $65^{\circ} \mathrm{C}$. 


\section{(ii) Chemical and physical characterizations:}

The spectroscopic and physicochemical techniques: CHN elemental analysis, Raman, UVvisible, ${ }^{1} \mathrm{H}$ NMR, and IR spectroscopies; SEM; and thermogravimetry were used to characterize the obtained complexes.

\section{Experimental}

\subsection{Materials}

Commercially available materials were used as received without further modification. These were bought from commercial sources (Merck and Fulka chemical companies). Tris(hydroxymethyl)aminomethane (THAM); $121.14 \mathrm{~g} / \mathrm{mol}$; purity $\geq 99.8 \%$ ), $\mathrm{SrCl}_{2} \cdot 6 \mathrm{H}_{2} \mathrm{O}$ (266.62 g/mol; purity 99\%), $\mathrm{BaCl}_{2} \cdot 2 \mathrm{H}_{2} \mathrm{O}$ (244.26g/mol; purity 99.99\%), $\mathrm{CaCl}_{2}$ (110.98 $\mathrm{g} / \mathrm{mol}$; purity $99.99 \%), \mathrm{MgCl}_{2}$ (95.21 g/mol; purity $\geq 98 \%$ ), and HPLC-grade methanol were of analytical grade chemicals and were used as bought. Water purification unit (Milli-Q) was used to generate the pure deionized water for the preparation of solutions.

\subsection{Synthesis}

The THAM (2.0 mmol) was dissolved in $25 \mathrm{~mL} \mathrm{MeOH}$, then added gradually to an aqueous solution containing $1.0 \mathrm{mmol}(20 \mathrm{~mL})$ of the respective metal chloride salt [Ba(II), $\mathrm{Ca}$ (II), $\mathrm{Sr}(\mathrm{II})$, and $\mathrm{Mg}(\mathrm{II})]$. The $\mathrm{pH}$ of the four solutions was adjusted to 8-9 using 5\% ammonia solution, then the solutions were refluxed at $65^{\circ} \mathrm{C}$ under stirring for 30 minutes. After that, the four solutions were slow cooled gradually and left overnight at room temperature affording colorless precipitates. Filtration, washing two times with $\mathrm{MeOH}$, and subsequent drying in vacuum for $48 \mathrm{~h}$ yielded the pure products as colorless powders. The products were next characterized by spectroscopies $\left({ }^{1} \mathrm{H}\right.$ NMR, Raman, IR, and UV-visible) as well as thermal and elemental analyses.

\subsection{Methods}

The UV-visible, ${ }^{1} \mathrm{H}$ NMR, Raman and IR spectra of the synthesized complexes were collected by Perkin-Elmer Lambda $25 \mathrm{UV} / \mathrm{Vis}$ spectrophotometer, Bruker DRX-250 spectrometer, Bruker FT-Raman spectrophotometer, and Shimadzu FT-IR spectrophotometer at room temperature, respectively.

The thermal and elemental data of the synthesized complexes were collected using Shimadzu TGA-50H thermal analyzer and Perkin-Elmer 2400CHN elemental analyzer, respectively. Surface morphologies of the synthesized complexes were pictured using Quanta FEG 250 SEM instrument.

\section{Results and discussion}

\subsection{Composition and UV-visible spectra}

The $\mathrm{Ba}$ (II), Ca (II), Sr (II), and $\mathrm{Mg}$ (II) chloride salts were dissolved in deionized water, where THAM was dissolved in $\mathrm{MeOH}$ solvent. No precipitates were seen when the 
methanolic solution of THAM $\left(\mathrm{C}_{4} \mathrm{H}_{11} \mathrm{NO}_{3}\right)$ was mixed with each aqueous solution of chloride salts. When the $\mathrm{pH}$ of each mixture reached $\sim 8.5$ by adding ammonia solution $(5 \%)$, one $\mathrm{OH}$ group in the THAM $\left(\mathrm{C}_{4} \mathrm{H}_{11} \mathrm{NO}_{3}\right)$ ligand is deprotonated and converted to the $\left(\mathrm{C}_{4} \mathrm{H}_{10} \mathrm{NO}_{3}{ }^{-} ; \mathrm{L}^{-}\right)$ chelate. All $\mathrm{Ba}(\mathrm{II}), \mathrm{Ca}(\mathrm{II}), \mathrm{Sr}(\mathrm{II})$, and $\mathrm{Mg}(\mathrm{II})$ ions formed a colorless product with $\mathrm{L}^{-}$chelate, and the elemental analyses data for these products are:

i) $\left[\mathrm{MgL}_{2}\left(\mathrm{H}_{2} \mathrm{O}\right)_{2}\right] \cdot 4 \mathrm{H}_{2} \mathrm{O}$ complex:

Gross formula, $\mathrm{C}_{8} \mathrm{H}_{32} \mathrm{~N}_{2} \mathrm{O}_{12} \mathrm{Mg}$; Molecular weight, $372.63 \mathrm{~g} \mathrm{~mol}^{-1}$; Elemental results: calc. (found) for C, 25.76\% (25.58); H, 8.59\% (8.31); N, 7.51\% (7.73); Mg, 6.52\% (6.77).

ii) $\left[\mathrm{CaL}_{2}\left(\mathrm{H}_{2} \mathrm{O}\right)_{2}\right] \cdot 2 \mathrm{H}_{2} \mathrm{O}$ complex:

Gross formula, $\mathrm{C}_{8} \mathrm{H}_{28} \mathrm{~N}_{2} \mathrm{O}_{10} \mathrm{Ca}$; Molecular weight, $352.38 \mathrm{~g} \mathrm{~mol}^{-1}$; Elemental results: calc. (found) for C, 27.24\% (27.43); H, 7.95\% (7.73); N, 7.95\% (8.17); Ca, 11.35\% (11.16).

iii) $\left[\mathrm{SrL}_{2}\left(\mathrm{H}_{2} \mathrm{O}\right)_{2}\right]$ complex:

Gross formula, $\mathrm{C}_{8} \mathrm{H}_{24} \mathrm{~N}_{2} \mathrm{O}_{8} \mathrm{Sr}$; Molecular weight, $363.89 \mathrm{~g} \mathrm{~mol}^{-1}$; Elemental results: calc. (found) for C, 26.38\% (26.23); H, 6.60\% (6.36); N, 7.70\% (7.49); Sr, 24.08\% (24.35).

iv) $\left[\mathrm{BaL}_{2}\left(\mathrm{H}_{2} \mathrm{O}\right)_{2}\right]$ complex:

Gross formula, $\mathrm{C}_{8} \mathrm{H}_{24} \mathrm{~N}_{2} \mathrm{O}_{8} \mathrm{Ba}$; Molecular weight, $413.60 \mathrm{~g} \mathrm{~mol}{ }^{-1}$; Elemental results: calc.(found) for C, 23.21\% (23.39); H, 5.80\% (5.55); N, 6.77\% (7.03); Ba, 33.20\% (33.40).

These data indicated that the reaction stoichiometry is 2:1 ( $\mathrm{L}^{-}$: Metal ion), which suggested that the general composition of the complexes obtained with $\mathrm{Ba}$ (II), $\mathrm{Ca}$ (II), $\mathrm{Sr}$ (II) and $\mathrm{Mg}(\mathrm{II})$ ions are $\left[\mathrm{BaL}_{2}\left(\mathrm{H}_{2} \mathrm{O}\right)_{2}\right], \quad\left[\mathrm{CaL}_{2}\left(\mathrm{H}_{2} \mathrm{O}\right)_{2}\right] \cdot 2 \mathrm{H}_{2} \mathrm{O}, \quad\left[\mathrm{SrL}_{2}\left(\mathrm{H}_{2} \mathrm{O}\right)_{2}\right], \quad$ and $\left[\mathrm{MgL}_{2}\left(\mathrm{H}_{2} \mathrm{O}\right)_{2}\right] \cdot 4 \mathrm{H}_{2} \mathrm{O}$, respectively, UV-visible spectra of the complexes were recorded over the 200-1000 nm wavelength range, showed that all the complexes gave one sharp and intense band with the wavenumber range from 300 to $350 \mathrm{~nm}$. All the observed bands had one sharp head centered at $305 \mathrm{~nm}$. This band may be assignable to the $\mathrm{M} \rightarrow \mathrm{L}$ charge transfer transitions. The band becomes more broad and strong in intensity in complexes of $\mathrm{Mg}(\mathrm{II})$ and $\mathrm{Ba}(\mathrm{II})$ ions, and much broad and very strong in intensity in a complex of $\mathrm{Sr}(\mathrm{II})$ ion.

\subsection{Vibrational spectroscopy}

The IR spectrum of each complex was scanned in the wavenumber range $400-4000 \mathrm{~cm}^{-1}$ and displayed in Figure 2. The band assignments for the important IR bands in free THAM and the complexes are given below:

IR data $\left(\mathrm{cm}^{-1}\right)$ for free THAM: $3351 v(\mathrm{O}-\mathrm{H}), 3195 \mathrm{v}(\mathrm{N}-\mathrm{H}), 2938 v(\mathrm{C}-\mathrm{H}), 1545 \delta_{\text {def }}(\mathrm{N}-\mathrm{H}), 1462$ $\delta_{\text {sciss }}\left(\mathrm{CH}_{2}\right), 1400 \delta(\mathrm{O}-\mathrm{H}), 1292 v(\mathrm{C}-\mathrm{N}), 1215 v(\mathrm{C}-\mathrm{C}), 1150 \delta_{\text {rock }}\left(\mathrm{CH}_{2}\right), 1039 v(\mathrm{C}-\mathrm{O})$, and 780 $\delta_{\text {wag }}\left(\mathrm{CH}_{2}\right)$.

IR data $\left(\mathrm{cm}^{-1}\right)$ for $\left[\mathrm{MgL}_{2}\left(\mathrm{H}_{2} \mathrm{O}\right)_{2}\right] \cdot 4 \mathrm{H}_{2} \mathrm{O}$ complex: $3325 \mathrm{v}(\mathrm{O}-\mathrm{H}), 3185 v(\mathrm{~N}-\mathrm{H}), 2977-2824$ $v\left(\mathrm{CH}_{2}\right), 1623 \delta_{\mathrm{b}}\left(\mathrm{H}_{2} \mathrm{O}\right), 1543 \delta_{\text {def }}(\mathrm{N}-\mathrm{H}), 1460 \delta_{\text {sciss }}\left(\mathrm{CH}_{2}\right), 1393 \delta(\mathrm{O}-\mathrm{H}), 1295 v(\mathrm{C}-\mathrm{N}), 1220$ 
$v(\mathrm{C}-\mathrm{C}), 1153 \delta_{\text {rock }}\left(\mathrm{CH}_{2}\right), 1027 \quad v(\mathrm{C}-\mathrm{O}), 760 \delta_{\text {wag }}\left(\mathrm{CH}_{2}\right), \quad 666 \delta_{\mathrm{w}}\left(\mathrm{H}_{2} \mathrm{O}\right), 594 \delta_{\mathrm{t}}\left(\mathrm{H}_{2} \mathrm{O}\right)$, and 540 $v(\mathrm{Mg}-\mathrm{O})$.

IR data $\left(\mathrm{cm}^{-1}\right)$ for $\left[\mathrm{CaL}_{2}\left(\mathrm{H}_{2} \mathrm{O}\right)_{2}\right] \cdot 2 \mathrm{H}_{2} \mathrm{O}$ complex: $3317 \mathrm{v}(\mathrm{O}-\mathrm{H}), 3188 \mathrm{v}(\mathrm{N}-\mathrm{H}), 2932-2824$ $v\left(\mathrm{CH}_{2}\right), 1629 \delta_{\mathrm{b}}\left(\mathrm{H}_{2} \mathrm{O}\right), 1547 \delta_{\text {def }}(\mathrm{N}-\mathrm{H}), 1458 \delta_{\text {sciss }}\left(\mathrm{CH}_{2}\right), 1399 \delta(\mathrm{O}-\mathrm{H}), 1293 v(\mathrm{C}-\mathrm{N}), 1221$ $v(\mathrm{C}-\mathrm{C}), 1172 \delta_{\text {rock }}\left(\mathrm{CH}_{2}\right), 1025 \quad v(\mathrm{C}-\mathrm{O}), 790 \delta_{\text {wag }}\left(\mathrm{CH}_{2}\right), 660 \delta_{\mathrm{w}}\left(\mathrm{H}_{2} \mathrm{O}\right), 600 \delta_{\mathrm{t}}\left(\mathrm{H}_{2} \mathrm{O}\right)$, and 542 $v(\mathrm{Ca}-\mathrm{O})$.

IR data $\left(\mathrm{cm}^{-1}\right)$ for $\left[\mathrm{SrL}_{2}\left(\mathrm{H}_{2} \mathrm{O}\right)_{2}\right]$ complex: $3318 v(\mathrm{O}-\mathrm{H}), 3090 v(\mathrm{~N}-\mathrm{H}), 2975-2856 v\left(\mathrm{CH}_{2}\right)$, $1627 \delta_{\mathrm{b}}\left(\mathrm{H}_{2} \mathrm{O}\right), 1546 \delta_{\text {def }}(\mathrm{N}-\mathrm{H}), 1450 \delta_{\text {sciss }}\left(\mathrm{CH}_{2}\right), 1410 \delta(\mathrm{O}-\mathrm{H}), 1290 v(\mathrm{C}-\mathrm{N}), 1227 v(\mathrm{C}-\mathrm{C})$, $1166 \delta_{\text {rock }}\left(\mathrm{CH}_{2}\right), 1023 v(\mathrm{C}-\mathrm{O}), 753 \delta_{\text {wag }}\left(\mathrm{CH}_{2}\right), 665 \delta_{\mathrm{w}}\left(\mathrm{H}_{2} \mathrm{O}\right), 612 \delta_{\mathrm{t}}\left(\mathrm{H}_{2} \mathrm{O}\right)$, and $536 v(\mathrm{Sr}-\mathrm{O})$. IR data $\left(\mathrm{cm}^{-1}\right)$ for $\left[\mathrm{BaL}_{2}\left(\mathrm{H}_{2} \mathrm{O}\right)_{2}\right]$ complex: $3320 v(\mathrm{O}-\mathrm{H}), 3187 v(\mathrm{~N}-\mathrm{H}), 2929-2800 v\left(\mathrm{CH}_{2}\right)$, $1632 \delta_{\mathrm{b}}\left(\mathrm{H}_{2} \mathrm{O}\right), 1545 \delta_{\text {def }}(\mathrm{N}-\mathrm{H}), 1452 \delta_{\text {sciss }}\left(\mathrm{CH}_{2}\right), 1400 \delta(\mathrm{O}-\mathrm{H}), 1291 v(\mathrm{C}-\mathrm{N}), 1212 v(\mathrm{C}-\mathrm{C})$, $1154 \delta_{\text {rock }}\left(\mathrm{CH}_{2}\right), 1025 v(\mathrm{C}-\mathrm{O}), 785 \delta_{\text {wag }}\left(\mathrm{CH}_{2}\right), 667 \delta_{\mathrm{w}}\left(\mathrm{H}_{2} \mathrm{O}\right), 608 \delta_{\mathrm{t}}\left(\mathrm{H}_{2} \mathrm{O}\right)$, and $520 v(\mathrm{Ba}-\mathrm{O})$.

Free THAM showed several distinguished absorption bands in its IR spectrum [Chen et al., 2018]. Two extraordinarily strong and broad bands located at $3351 \mathrm{~cm}^{-1}$ and $3195 \mathrm{~cm}^{-1}$ were attributed to the vibrations of $v(\mathrm{O}-\mathrm{H})$ and $\mathrm{v}(\mathrm{N}-\mathrm{H})$, respectively. A group of medium and sharp bands appears within the range 1600-1200 $\mathrm{cm}^{-1}$, exactly at $1589 \mathrm{~cm}^{-1}, 1462 \mathrm{~cm}^{-1}, 1292 \mathrm{~cm}^{-1}$ and $1215 \mathrm{~cm}^{-1}$, were resulted from the $\delta_{\text {def }}(\mathrm{N}-\mathrm{H}), \delta_{\text {sciss }}\left(\mathrm{CH}_{2}\right), v(\mathrm{C}-\mathrm{N})$ and $v(\mathrm{C}-\mathrm{C})$ vibrations, respectively. Band with very strong intensity and medium in broadening was located at 1034 $\mathrm{cm}^{-1}$ and was attributed to the $v(\mathrm{C}-\mathrm{C})$ vibrations. When THAM complexed with $\mathrm{Mg}(\mathrm{II})$, $\mathrm{Sr}(\mathrm{II}), \mathrm{Ba}(\mathrm{II})$, and $\mathrm{Ca}(\mathrm{II})$ ions, the intensity and broadening of the bands due to the $v(\mathrm{~N}-\mathrm{H})$ and $v(\mathrm{O}-\mathrm{H})$ vibrations were decreased. The frequency of the $v(\mathrm{O}-\mathrm{H})$ vibrations was significantly shifted from $3351 \mathrm{~cm}^{-1}$ in the free THAM to $3325-3317 \mathrm{~cm}^{-1}$ in the complexes, where the frequency of the $v(\mathrm{~N}-\mathrm{H})$ vibrations was slightly shifted from $3195 \mathrm{~cm}^{-1}$ in the free THAM to $3190-3185 \mathrm{~cm}^{-1}$ in the complexes. The band of $v(\mathrm{C}-\mathrm{O})$ occurs near $1039 \mathrm{~cm}^{-1}$ in the free THAM and was moved to a lower frequency in the complexes $\left(1027-1023 \mathrm{~cm}^{-1}\right)$. The bands attributed to the $\delta_{\operatorname{def}}(\mathrm{N}-\mathrm{H})$ and $v(\mathrm{C}-\mathrm{N})$ vibrations, remained in the same position as observed in the free THAM, along with the slight shifts in the $v(\mathrm{~N}-\mathrm{H})$ vibrations, which means that $\mathrm{NH}_{2}$ group do not participate in the complexation. Coordinated water molecules exhibits four angular deformation motion around $1630 \mathrm{~cm}^{-1}, 851 \mathrm{~cm}^{-1}, 645 \mathrm{~cm}^{-1}$ and $582 \mathrm{~cm}^{-}$ ${ }^{1}$ attributed to the $\delta_{\mathrm{b}}$ (bend), $\delta_{\mathrm{r}}($ rock $), \delta_{\mathrm{w}}($ wag $)$ and $\delta_{\mathrm{t}}$ (twist) vibrations, respectively [Deacon \& Phillips, 1980].

Only the band due to the $\delta_{\mathrm{r}}$ (rock)vibration was not detected in the spectrum of each complex due to the overlapping of this band with other vibrational bands. The $\delta_{b}\left(\mathrm{H}_{2} \mathrm{O}\right)$ vibration appeared within the range of $1632-1623 \mathrm{~cm}^{-1}$, that of the $\delta_{\mathrm{w}}\left(\mathrm{H}_{2} \mathrm{O}\right)$ vibration appeared within the range of $667-660 \mathrm{~cm}^{-1}$, while the vibration of $\delta_{\mathrm{t}}\left(\mathrm{H}_{2} \mathrm{O}\right)$ was found within the range of $612-594 \mathrm{~cm}^{-1}$. The weak bands noticed in the range of $540-520 \mathrm{~cm}^{-1}$ could be attributed to the $v(\mathrm{M}-\mathrm{O})$ in the complexes. Figure 3 illustrates the laser Raman spectra of free THAM, and the complexes scanned in the wavenumber region $50-400 \mathrm{~cm}^{-1}$. 

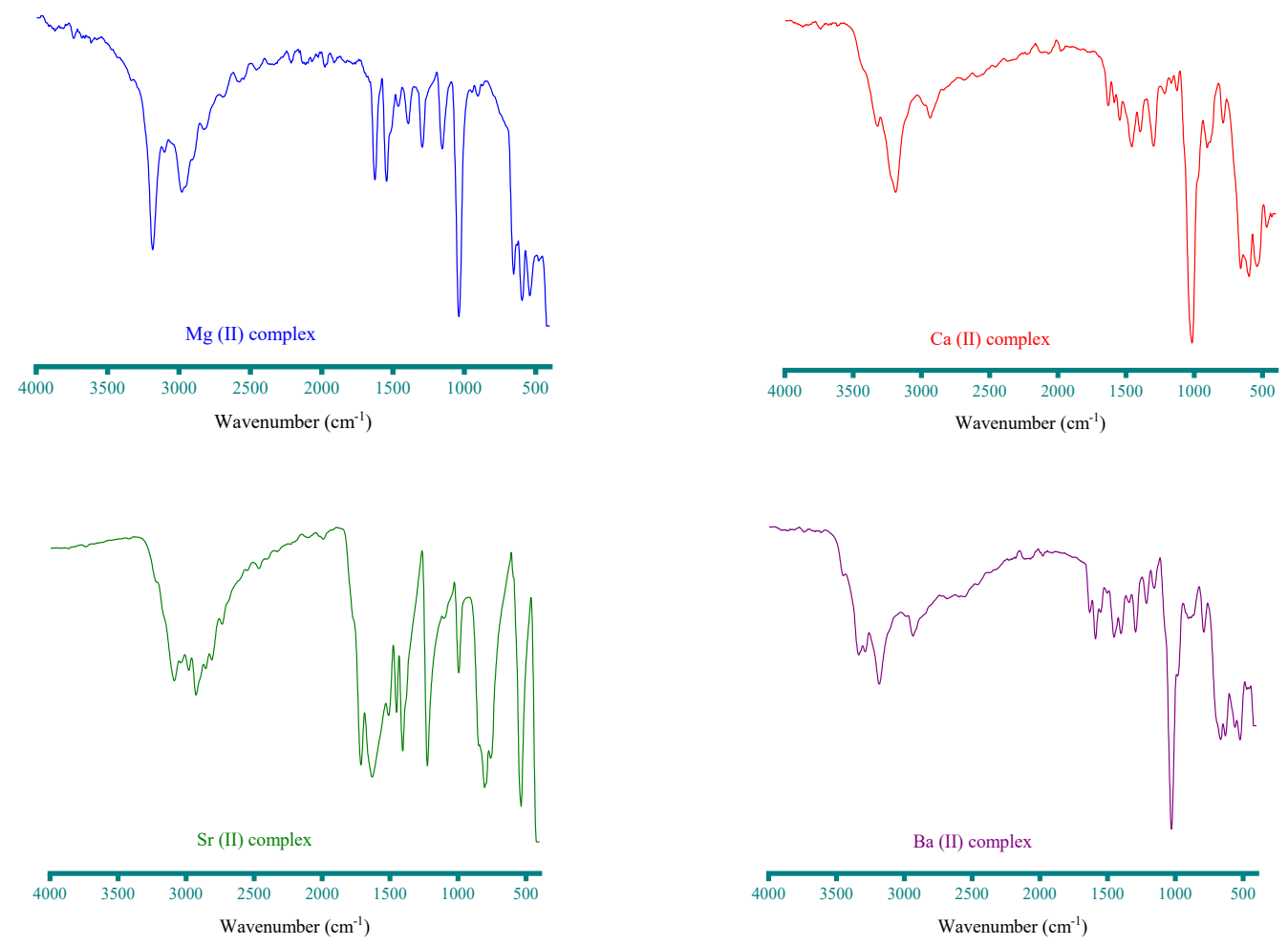

Fig. 2. IR spectra of the $\mathrm{Ba}(\mathrm{II}), \mathrm{Ca}(\mathrm{II}), \mathrm{Sr}(\mathrm{II})$, and $\mathrm{Mg}(\mathrm{II})$ complexes.

The Raman spectrum of free THAM showed four sharp and very strong bands at $1471 \mathrm{~cm}^{-1}$, $1258 \mathrm{~cm}^{-1}, 1071 \mathrm{~cm}^{-1}$, and $804 \mathrm{~cm}^{-1}$ resulting from the $\delta_{\text {sciss }}\left(\mathrm{CH}_{2}\right), v(\mathrm{C}-\mathrm{N}), v(\mathrm{C}-\mathrm{O})$ and $\delta_{\text {wag }}\left(\mathrm{CH}_{2}\right)$ vibrations, respectively. Also, THAM shows a strong and broadband around 2945$2850 \mathrm{~cm}^{-1}$ assigned to the $\mathrm{v}(\mathrm{C}-\mathrm{H})$ vibrations. The medium and sharp band located at 3287 $\mathrm{cm}^{-1}$ could be assigned to the $v(\mathrm{O}-\mathrm{H})$ vibration. In the Raman spectra of the complexes (Figure 3 ), the $\delta_{\text {sciss }}\left(\mathrm{CH}_{2}\right), v(\mathrm{C}-\mathrm{N}), v(\mathrm{C}-\mathrm{O})$ and $\delta_{\text {wag }}\left(\mathrm{CH}_{2}\right)$ vibrational bands have been registered in the region 1466-1464 $\mathrm{cm}^{-1}, 1270-1255 \mathrm{~cm}^{-1}, 1050-1045 \mathrm{~cm}^{-1}$, and $800-758 \mathrm{~cm}^{-1}$, respectively. Based on elemental and vibrational spectral results, proposed structures of the synthesized complexes were given in Figure 4.
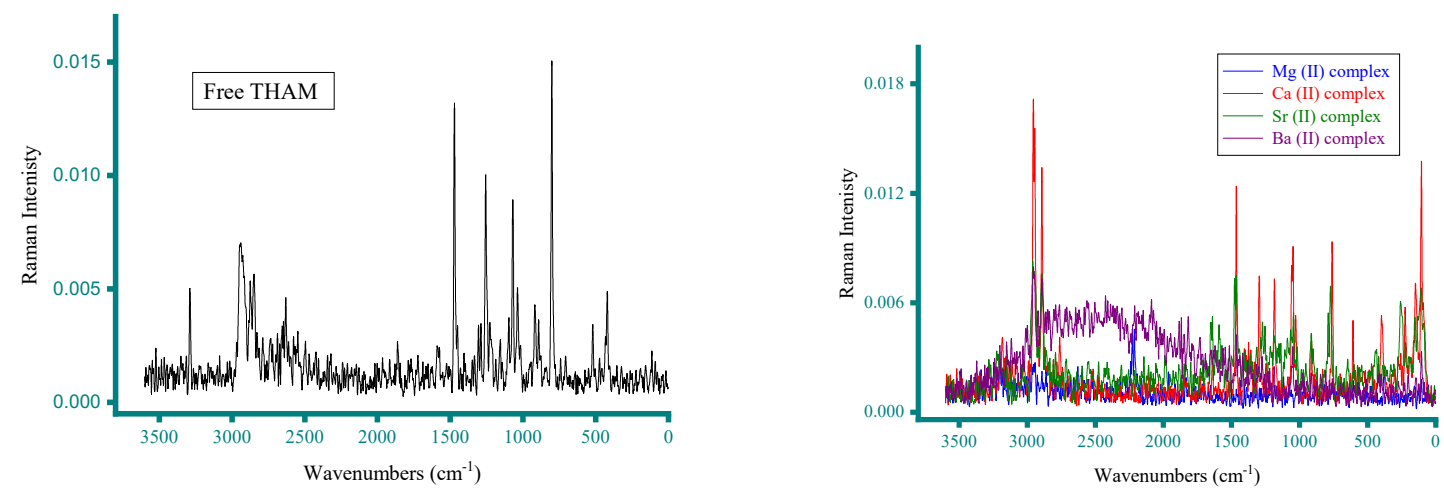

Fig. 3. Laser Raman spectra of free THAM, $\mathrm{Ba}(\mathrm{II}), \mathrm{Ca}(\mathrm{II}), \mathrm{Sr}(\mathrm{II})$, and $\mathrm{Mg}(\mathrm{II})$ complexes. 
<smiles>NC1(CO)COC(N)(CO)CO[Al](O)(O)OC1</smiles><smiles>NC1(CO)COC2(O)OCC(N)(CO)OC2(O)OC1</smiles><smiles>NC(CO)(CO)CO[Si]1(O)OC(N)(CO)CO[Si]1(O)O</smiles><smiles></smiles>

Fig. 4. Proposed chemical structures of $\mathrm{Ba}(\mathrm{II}), \mathrm{Sr}(\mathrm{II}), \mathrm{Ca}(\mathrm{II})$, and $\mathrm{Mg}(\mathrm{II})$ complex.

\section{$3.3{ }^{1} \mathrm{H}$ NMR spectroscopy}

The ${ }^{1} \mathrm{H}$ NMR spectrum (DMSO- $d_{6}$ ) of free THAM and $\mathrm{Ba}(\mathrm{II})$ complex has been obtained at room temperature, where their chemical shifts were listed in Table 1. The resultant data of free THAM were: $\delta=2.58\left(\mathrm{~s}, 6 \mathrm{H}, 3 \mathrm{CH}_{2}\right), 3.48(\mathrm{~s}, 3 \mathrm{H}, 3 \mathrm{OH}), 7.64\left(\mathrm{~s}, 2 \mathrm{H}, \mathrm{NH}_{2}\right)$. The resultant data of $\mathrm{Ba}(\mathrm{II})$ complex were: $\delta=2.57\left(\mathrm{~s}, 12 \mathrm{H}, 6 \mathrm{CH}_{2}\right), 3.45(\mathrm{~s}, 4 \mathrm{H}, 4 \mathrm{OH}), 7.83\left(\mathrm{~s}, 4 \mathrm{H}, 2 \mathrm{NH}_{2}\right)$. Free THAM produced three signals in the 2.58-7.64 range, and all these signals were detected in the spectrum of the complex with $\mathrm{Ba}$ (II) ion. In the spectrum of free THAM, the protons of $\mathrm{CH}_{2}, \mathrm{OH}$ and $\mathrm{NH}_{2}$ groups resonated at 2.58, 3.48, and $7.64 \mathrm{ppm}$, respectively. In the spectrum of $\mathrm{Ba}$ (II) complex, the protons of $\mathrm{OH}$, and $\mathrm{CH}_{2}$ groups were represented slightly up-field shifts. The $\mathrm{NH}_{2}$ protons were undergone down-field shifted and exhibited a definite singlet at $7.83 \mathrm{ppm}$. The protons of coordinated water molecules showed a broad signal at $3.52 \mathrm{ppm}$. 
Table 1. The ${ }^{1} \mathrm{H}$ NMR data (ppm) of free THAM and Ba(II) complex.

\begin{tabular}{|c|c|c|c|}
\hline Compound & $\begin{array}{c}\mathrm{CH} \text { (s, 6H) } \\
\text { methylene group }\end{array}$ & $\begin{array}{c}\mathrm{OH}(\mathrm{s}, 3 \mathrm{H}) \\
\mathrm{OH} \text { group }\end{array}$ & $\begin{array}{c}\mathrm{NH}_{2}(\mathrm{~s}, 2 \mathrm{H}) \\
\mathrm{NH}_{2} \text { group }\end{array}$ \\
\hline Free THAM & 2.58 & 3.48 & 7.64 \\
\hline $\mathrm{Ba}(\mathrm{II})$ complex & 2.57 & 3.45 & 7.83 \\
\hline
\end{tabular}

\subsection{Thermogravimetry}

The Compositions and structures of the complexes were confirmed by thermogravimetry. Figure 5 presents the thermograms of the free THAM, $\mathrm{Ba}(\mathrm{II}), \mathrm{Ca}(\mathrm{II}), \mathrm{Sr}(\mathrm{II})$, and $\mathrm{Mg}(\mathrm{II})$ complex. The obtained thermograms enabled the following observations:

i) The free THAM was thermally stable up to $\sim 180{ }^{\circ} \mathrm{C}$. After complexation resulted in a new $\mathrm{Mg}$ (II) compound with decreasing the stability to $\sim 120^{\circ} \mathrm{C}$. Complexation of THAM with the $\mathrm{Ba}(\mathrm{II})$ and $\mathrm{Sr}$ (II) ions led to un-stable complexes, these complexes start to decompose at $\sim 30$ ${ }^{\circ} \mathrm{C}$

ii) Complexation of THAM with $\mathrm{Ca}$ (II) ion formed a highly stable complex. After losing the lattice water molecules at around $80{ }^{\circ} \mathrm{C}$, the complex remained thermally stable up to $\sim 240$ ${ }^{\circ} \mathrm{C}$.

iii) Complexes of $\mathrm{Mg}$ (II) and $\mathrm{Ca}$ (II) ions are stable at room temperature and can be stored without any degradation.

iv) Free THAM, and the complexes with $\mathrm{Mg}$ (II) and $\mathrm{Ca}$ (II) ions were decomposed in a onestage degradation step in the temperature range of $180-320{ }^{\circ} \mathrm{C}, 120-400{ }^{\circ} \mathrm{C}$ and $240-625^{\circ} \mathrm{C}$, respectively. While the complexes with $\mathrm{Ba}(\mathrm{II})$ and $\mathrm{Sr}(\mathrm{II})$ ions were decomposed in two-stage degradation step in the temperature range of $30-320{ }^{\circ} \mathrm{C}$, and $320-800{ }^{\circ} \mathrm{C}$ for $\mathrm{Ba}(\mathrm{II})$ complex, and in the temperature range of $30-300{ }^{\circ} \mathrm{C}$ and $300-800^{\circ} \mathrm{C}$ for $\mathrm{Sr}(\mathrm{II})$ complex.

v) The decompositions of complexes were almost completed leaving $\mathrm{MgO}$ for $\mathrm{Mg}$ (II) complex, $\mathrm{BaCO}_{3}, \mathrm{SrCO}_{3}$, and $\mathrm{CaCO}_{3}$ for other complexes as the final decomposition products. All these products were contaminated with some residual carbons. 


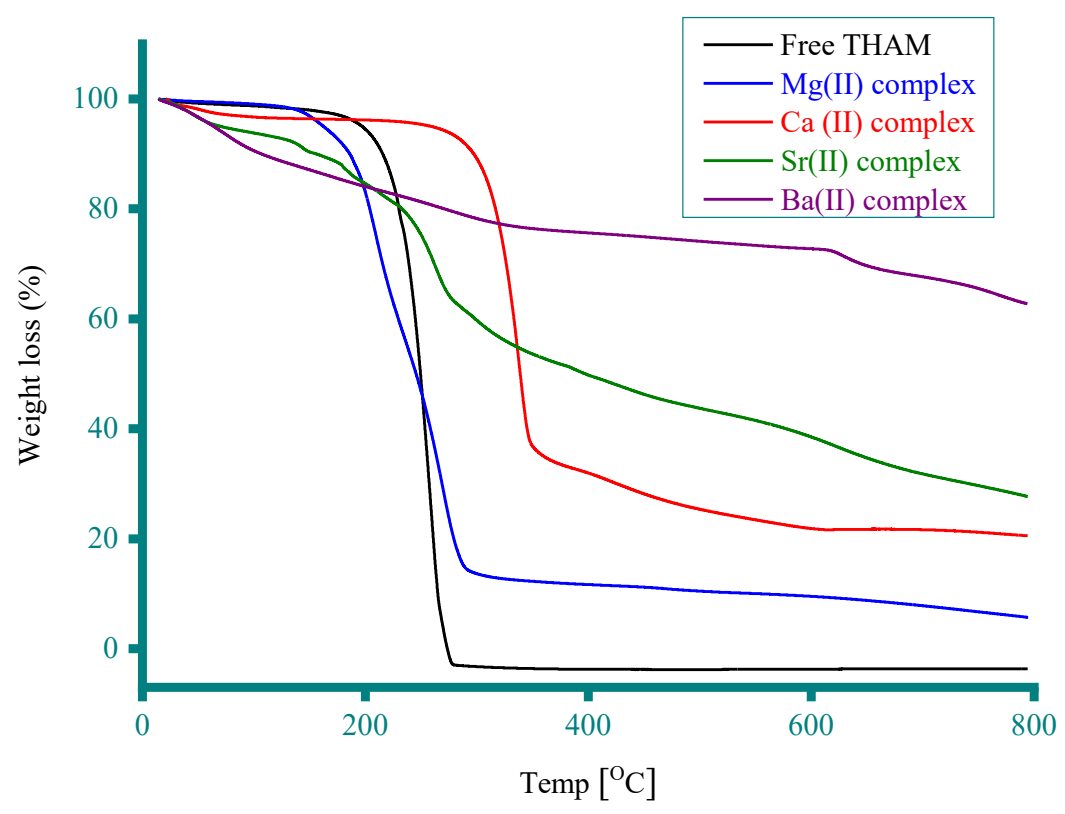

Fig. 5. Thermograms of free THAM, $\mathrm{Ba}(\mathrm{II}), \mathrm{Ca}(\mathrm{II}), \mathrm{Sr}(\mathrm{II})$, and $\mathrm{Mg}(\mathrm{II})$ complexes.

\subsection{Structural morphologies}

Scanning electron microscope (SEM) is the most frequently used technique for collecting specific outer surface-related information:

$i$ - Surface topology.

ii- Microstructure and composition.

iii- Porous structure of the surface.

Surface morphologies of the synthesized complexes were pictured using a Quanta FEG 250 SEM instrument and are presented in Figure 6. These pictures were taken at different levels of magnification ranging from 2000 to $\mathrm{x} 10,000$. The SEM pictures of $\mathrm{Ba}(\mathrm{II}), \mathrm{Ca}(\mathrm{II}), \mathrm{Sr}(\mathrm{II})$, and $\mathrm{Mg}(\mathrm{II})$ complexes indicated that the particles of these complexes have a distinct size and morphology, and all have short rod-like morphology. This specific morphology was clearly observed for particles consisting $\mathrm{Sr}$ (II) and $\mathrm{Mg}$ (II) complexes. The rods of these two complexes were well-developed and had clear shapes, dimensions, and clear features. The short rod-like morphology was not obviously observed for particles of the $\mathrm{Ca}$ (II) and $\mathrm{Ba}(\mathrm{II})$ complexes. For a $\mathrm{Ca}$ (II) complex, several rods were broken into small pieces so that it appeared that these particles had no complete formation into rods. For $\mathrm{Ba}$ (II) complex, small granules were accumulated on the surface of a number of rods, indicating that a type of deformation had occurred to these rods. The particles of $\mathrm{Mg}(\mathrm{II})$ complex had a well-defined shape and a well-homogeneous and uniform matrix. 


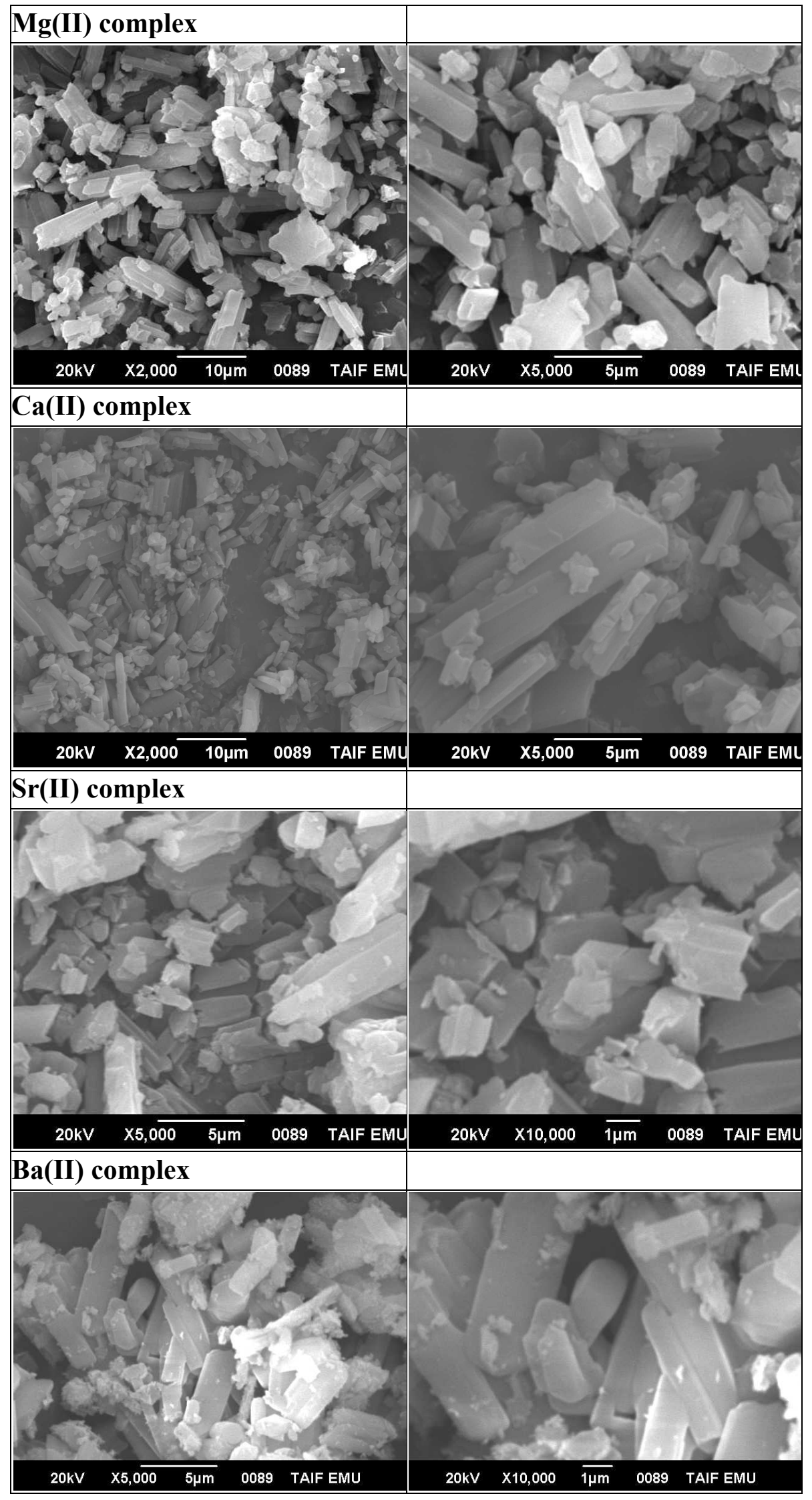

Fig. 6. $\mathrm{SEM}$ micrographs of $\mathrm{Ba}(\mathrm{II}), \mathrm{Ca}(\mathrm{II}), \mathrm{Sr}(\mathrm{II})$, and $\mathrm{Mg}(\mathrm{II})$ complexes. 


\section{Conclusion}

Octahedral metal complexes of THAM with the ions $\mathrm{Ba}(\mathrm{II}), \mathrm{Ca}(\mathrm{II}), \mathrm{Sr}(\mathrm{II})$, and $\mathrm{Mg}(\mathrm{II})$ were prepared, and their structures were characterized using UV-visible, IR, Raman, and ${ }^{1} \mathrm{H}$ NMR spectroscopies and other physicochemical and analytical methods (elemental analysis, thermogravimetry, and SEM). Colorless products were obtained by the reaction of THAM with the metal ions with a stoichiometry of $2: 1$ (Ligand: Metal ion) at $65{ }^{\circ} \mathrm{C}$ and $\mathrm{pH}$ of $\sim 8.5$. Under these conditions, the THAM molecule $\left(\mathrm{C}_{4} \mathrm{H}_{11} \mathrm{NO}_{3}\right)$ losses a hydrogen atom and is transferred to the $\left(\mathrm{C}_{4} \mathrm{H}_{10} \mathrm{NO}_{3}{ }^{-} ; \mathrm{L}^{-}\right)$chelate with the metal ions forming colorless products. These products were formulated as $\left[\mathrm{BaL}_{2}\left(\mathrm{H}_{2} \mathrm{O}\right)_{2}\right],\left[\mathrm{CaL}_{2}\left(\mathrm{H}_{2} \mathrm{O}\right)_{2}\right] \cdot 2 \mathrm{H}_{2} \mathrm{O},\left[\mathrm{SrL}_{2}\left(\mathrm{H}_{2} \mathrm{O}\right)_{2}\right]$, and $\left[\mathrm{MgL}_{2}\left(\mathrm{H}_{2} \mathrm{O}\right)_{2}\right] \cdot 4 \mathrm{H}_{2} \mathrm{O}$, corresponding to the reaction of THAM with $\mathrm{Ba}(\mathrm{II}), \mathrm{Ca}(\mathrm{II}), \mathrm{Sr}(\mathrm{II})$, and $\mathrm{Mg}(\mathrm{II})$ ions, respectively. The morphology of the complexes was determined by SEM technique, and the obtained micrographs indicated that the complexes have short rod-like morphology.

\section{ACKNOWLEDGEMENTS}

This research was funded by the deanship of scientific research at Princess Nourah bint Abdulrahman University through the Fast-track Research Funding program.

\section{References}

Abdel Ghani, N.T. \& Mansour, A.M. (2011) Novel Pd (II) and Pt (II) complexes of N, Ndonor benzimidazole ligand: Synthesis, spectral, electrochemical, DFT studies and evaluation of biological activity. Inorganica Chimica Acta, 373, 249-258.

Abdel-Rahman, L.H., El-Khatib, R.M., Nassr, L.A.E., Abu-Dief, A.M., Mohamed, I. \& Amin, A.S. (2014) Metal based pharmacologically active agents: Synthesis, structural characterization, molecular modeling, CT-DNA binding studies and in vitro antimicrobial screening of iron(II) bromosalicylidene amino acid chelates. Spectrochimica Acta A, 117, 366-378.

Albishri, H.M. \& Marwani, H.M. (2016) Chemically modified activated carbon with tris (hydroxymethyl) aminomethane for selective adsorption and determination of gold in water samples. Arabian Journal of Chemistry, 9, S252-S258.

Alessio, E. (2011) Bioinorganic Medicinal Chemistry, Wiley-VCH Verlag GmbH and Co. KGaA.

Ali, F., Kamal, S., Shakeela, Q. and Ahmed, S. (2021) Extended-spectrumand Metallo-beta lactamase enzymesmediated resistance in Pseudomonas aeruginosa in clinically isolated specimens, Kuwait Journal of Science, 48(2), 1-10. 
Asgedom, G., Sreedhara, A. \& Rao, C.P. (1995) Oxovanadium(V) Schiff base complexes of tris(hydroxymethyl)aminomethane with salicylaldehyde and its derivatives: synthesis, characterization, and redox reactivity. Polyhedron, 14(13-14); 1995: 1873-1879.

Brignac, P.J. \& Mo, C. (1975) Formation constants and metal-to-ligand ratios for tris(hydroxymethyl)aminomethane-metal complexes. Analytical Chemistry, 47(8), 14651466.

Bubb, W.A., Berthon, H.A. \& Kuchel, P.W. (1995) Tris Buffer Reactivity with LowMolecular-Weight Aldehydes: NMR Characterization of the Reactions of Glyceraldehyde-3Phosphate. Bioorganic Chemistry, 23(2), 119-130.

Cao, Q., Li, Y., Freisinger, E., Qin, P.Z., Sigel, R.K.O. \& Mao, Z-W. (2017) G-quadruplex DNA targeted metal complexes acting as potential anticancer drugs. Inorganic Chemistry Frontiers, 4, 10-32.

Chen, X., Wu, S., Yi, M., Ge, J., Yin, G. \& Li, X. (2018) Preparation and physicochemical properties of blend films of feather keratin and poly (vinyl alcohol) compatibilized by tris (hydroxymethyl) aminomethane. Polymers, 10, 1054.

Crisóstomo-Lucas, C., García-Holley, P., Hernández-Ortega, S., Sánchez-Bartéz, F., Gracia-Mora, I. \& Barba-Behrens, N. (2015) Structural characterization and cytotoxic activity of tioconazole coordination compounds with cobalt (II), copper (II), zinc (II) and cadmium (II). Inorganica Chimica Acta, 438, 245-254.

Dabrowiak, J.C. (2017) Metals in Medicine, $2^{\text {nd }}$ ed., Wiley.

Dai, J., Dan, W., Ren, S., Shang, C. \& Wang, J. (2018) Design, synthesis and biological evaluations of quaternization harman analogues as potential antibacterial agents. European Journal of Medicinal Chemistry, 160, 23-36.

Dasari, S. \& Tchounwou, P.B. (2014) Cisplatin in cancer therapy: molecular mechanisms of action. European Journal of Pharmacology, 740, 364-378.

Deacon, G.B. \& Phillips, R.J. (1980) Relationships between the carbon-oxygen stretching frequencies of carboxylato complexes and the type of carboxylate coordination. Coordination Chemistry Reviews, 33(3), 227-250.

Deng, Y., Wang, X-Z., Huang, S-H. \& Li, C-H. (2019) Antibacterial activity evaluation of synthetic novel pleuromutilin derivatives in vitro and in experimental infection mice. European Journal of Medicinal Chemistry, 162, 194-202.

Dominelli, B., Correia, J.D.G. \& Kühn, F.E. (2018) Medicinal applications of gold (I/III)based complexes bearing $\mathrm{N}$-heterocyclic carbene and phosphine ligands. Journal of Organometallic Chemistry, 866, 153-164. 
El-Dissouky, A., Khalil, T.E., Elbadawy, H.A., El-Sayed, D.S., Attia, A.A. \& Foro, S. (2020) X-ray crystal structure, spectroscopic and DFT computational studies of H-bonded charge transfer complexes of tris (hydroxymethyl)aminomethane (THAM) with chloranilic acid (CLA). Journal of Molecular Structure, 1200, 127066.

Galluzzi, L., Senovilla, L., Vitale, I., Michels, J., Martins, I., Kepp, O., Castedo, M. \& Kroemer, G. (2012) Molecular mechanisms of cisplatin resistance. Oncogene, 31, 18691883.

Guidi, F., Modesti, A., Landini, I., Nobili, S., Mini, E., Bini, L., Puglia, M., Casini, A., Dyson, P.J., Gabbiani, C. \& Messori, L. (2013) The molecular mechanisms of antimetastatic ruthenium compounds explored through DIGE proteomics. Journal of Inorganic Biochemistry, 118, 94-99.

Hambley, T.W. (2001) Platinum binding to DNA: structural controls and consequences. Journal of the Chemical Society, Dalton Transactions, 2711-2718.

Hayashi, N., Kinemuchi, H. \& Kamijo, K. (1981) Effect of tris (hydroxymethyl) aminomethane on amine oxidase activity in dog brain, liver and serum and in human placenta. Japanese Journal of Pharmacology, 31(5), 737-746.

Howse, G.L., Bovill, R.A., Stephens, P.J. \& Osborn, H.M.I. (2019) Synthesis and antibacterial profiles of targeted triclosan derivatives. European Journal of Medicinal Chemistry, 162, 51-58.

Hu, K., Zhou, G., Zhang, Z., Li, F., Li, J. \& Liang, F. (2016) Two hydrazone copper (II) complexes: synthesis, crystal structure, cytotoxicity, and action mechanism. RSC Advances, 6, 36077-36084.

Kallet, R.H., Jasmer, R.M., Luce, J.M., Lin, L.H. \& Marks, J.D. (2000) The treatment of acidosis in acute lung injury with tris-hydroxymethyl aminomethane (THAM). American Journal of Respiratory and Critical Care Medicine, 161(4), 1149-1153.

Khan, T-M., Gul, N.S., Lu, X., Wei, J-H., Liu, Y-C., Sun, H., Liang, H., Orvig, C. \& Chen, Z-F. (2019) In vitro and in vivo anti-tumor activity of two gold (III) complexes with isoquinoline derivatives as ligands. European Journal of Medicinal Chemistry, 163, 333-343.

Köpf-Maier, P. (1994) Complexes of metals other than platinum as antitumour agents. European Journal of Clinical Pharmacology, 47, 1-16.

Lai, S., Jiang, G., Yao, J., Li, W., Han, B., Zhang, C., Zeng, C. \& Liu, Y. (2015) Cytotoxic activity, DNA damage, cellular uptake, apoptosis and western blot analysis of ruthenium (II) polypyridyl complex against human lung decarcinoma A549 cell. Journal of Inorganic Biochemistry, 152, 1-9. 
Lundblad, R.L. \& Macdonald, F. (2010) Preparation of Buffers for Use in Enzyme Studies: G. Gomori, Handbook of Biochemistry and Molecular Biology, CRC Press, pp. 739-742.

Maheswari, P.U., Ster, M., Smulders, S., Barends, S., Wezel, G.P., Massera, C., Roy, S., Dulk, H., Gamez, P. \& Reedijk, J. (2008) Structure, Cytotoxicity, and DNA-Cleavage Properties of the Complex [CuII(pbt)Br2]. Inorganic Chemistry, 47(9), 3719-3727.

Meng, T., Tang, S-F., Qin, Q-P., Liang, Y-L., Wu, C-X., Wang, C-Y., Yan, H-T., Dong, J-X. \& Liu, Y-C. (2016) Evaluation of the effect of iodine substitution of 8-hydroxyquinoline on its platinum (II) complex: cytotoxicity, cell apoptosis and telomerase inhibition. MedChemComm, 7, 1802-1811.

Mjos, K.D. \& Orvig, C. (2014) Metallodrugs in medicinal inorganic chemistry. Chemical Reviews, 114(8), 4540-4563.

Mohammed, Y.A., Baraki, T., Upadhyay, R.K. \& Masood, A. (2014) Spectro-magnetic and antimicrobial studies on some $3 \mathrm{~d}$ metal complexes with ethylenedianil of ortho-hydroxyphenylglyoxal. American Journal of Applied Chemistry, 2, 15-18.

Muhammad, N. \& Guo, Z. (2014) Metal-based anticancer chemotherapeutic agents. Current Opinion in Chemical Biology, 19, 144-153.

Murakami, S., Sudo, Y., Miyano, K., Nishimura, H., Matoba, M., Shiraishi, S., Konno, H. \& Uezono, Y. (2016) Tris-hydroxymethyl-aminomethane enhances capsaicin-induced intracellular Ca2+ influx through transient receptor potential V1 (TRPV1) channels. Journal of Pharmacological Sciences, 130(2), 72-77.

Nahas, G.G., Sutin, K.M., Fermon, C., Streat, S., Wiklund, L., Wahlander, S., Yellin, P., Brasch, H., Kanchuger, M., Capan, L., Manne, J., Helwig, H., Gaab, M., Pfenninger, E., Wetterberg, T., Holmdahl, M. \& Turndorf, H. (1998) Guidelines for the treatment of acidaemia with THAM. Drugs, 55, 191-224.

Odabasoglu, M., Albayrak, Ç., Büyükgüngör, O. \& Lönnecke, P. (2003) 2-\{[Tris (hydroxymethyl) methyl] aminomethylene cyclohexa-3, 5-dien-1 (2H)-one and its 6-hydroxy and 6-methoxy derivatives. Acta Crystallographica Section C, C59(11), o616-o619.

Pagoto, T.M.P., Sobrinho, L.L.G., Graminha, A.E., Guedes, A.P.M., Carroccia, M.C., de Oliveira, P.F., Silveira-Lacerda, E.P., Deflon, V.M., Tavares, D.C., Pivatto, M., Batista, A.A. \& Poelhsitz, G.V . (2015) A ruthenium (II) complex with the propionate ion: Synthesis, characterization and cytotoxic activity. Comptes Rendus Chimie, 18(12), 1313-1319.

Qin, Q-P., Wang, S-L., Tan, M-X., Liu, Y-C., Meng, T., Zou, B-Q. \& Liang, H. (2019) Synthesis of two platinum (II) complexes with 2-methyl-8-quinolinol derivatives as ligands and study of their antitumor activities. European Journal of Medicinal Chemistry, 161, 334342 . 
Saleem, K., Wani, W.A., Haque, A., Lone, M.N., Ali, I., Ming-Fa, H. \& Jairajpuri, M.A. (2013) Synthesis, DNA binding, hemolysis assays and anticancer studies of copper (II), nickel (II) and iron(III) complexes of a pyrazoline-based ligand, Future Medicinal Chemistry, 5, 135-146.

Sayadi, M., Sabounchei, S.J., Sedghi, A., Bayat, M., Hosseinzadeh, L. \& Gable, R.W. (2019) Synthesis, characterization, theoretical and cytotoxicity studies of Pd (II) and Pt (II) complexes with new bidentate carbon donor ligand. Polyhedron, 161, 179-188.

Singh, U., Malla, A.M., Bhat, I.A., Ahmad, A., Bukhari, M.N., Bhat, S., Anayutullah, S. \& Hashmi, A.A. (2016) Synthesis, molecular docking and evaluation of antifungal activity of $\mathrm{Ni}(\mathrm{II}), \mathrm{Co}(\mathrm{II})$ and $\mathrm{Cu}(\mathrm{II})$ complexes of porphyrin core macromolecular ligand. Microbial Pathogenesis, 93, 172-179.

Tarafder, M.H.T., Saravanan, N., Crouse, K.A. \& Ali, A.M. (2001) Coordination chemistry and biological activity of nickel(II) and copper(II) ion complexes with nitrogensulphur donor ligands derived from S-benzyldithiocarbazate (SBDTC). Transition Metal Chemistry, 26, 613-618.

Tatar, L., Nazır, H., Gümüsşer, M., Kale, C. \& Atakol, O. (2005) Synthesis, crystal structure and electrochemical behaviour of water soluble Schiff bases. Zeitschrift für Kristallographie - Crystalline Materials, 220(7), 639-642.

Tavares, T.T., Azevedo, G.C., Garcia, A., Carpanez, A.G., Lewer, P.M., Paschoal, D., Müller, B.L., Dos Santos, H.F., Matos, R.C., Silva, H., Grazul, R.M. \& Fontes, A.P.S. (2017) Gold(I) complexes with aryl-thiosemicarbazones: Molecular modeling, synthesis, cytotoxicity and TrxR inhibition. Polyhedron, 132, 95-104.

Tella, A.C., Obaleye, J.A., Olawale, M.D., Ngororabanga, J.M.V., Ogunlaja, A.S. \& Bourned, S.A. (2019) Synthesis, crystal structure, and density functional theory study of a zinc(II) complex containing terpyridine and pyridine-2,6-dicarboxylic acid ligands: Analysis of the interactions with amoxicillin. Comptes Rendus Chimie, 22(1), 3-12.

Trudu, F., Amato, F., Vaňhara, P., Pivetta, T., Peña-Méndez, E.M. \& Havel, J. (2015) Coordination compounds in cancer: Past, present and perspectives. Journal of Applied Biomedicine, 13(2), 79-103.

Vakili, S., Asadikaram, G., Torkzadeh-Mahani, M., Behroozikhah, A., Nematollahi, M.H. \& Savardashtaki, A. (2021) Design and construction of a localized surface plasmon resonance-based goldnanobiosensor for rapid detection of brucellosis, Kuwait Journal of Science, 48(3), 1-9.

Walsh, T.R., Efthimiou, J. \& Dréno, B. (2016) Systematic review of antibiotic resistance in acne: an increasing topical and oral threat. Lancet Infectious Diseases, 16, e23-e33. 
Weber, T., Tschernich, H., Sitzwohl, C., Ullrich, R., Germann, P., Zimpfer, M., Sladen, R.N. \& Huemer, G. (2000) Tromethamine buffer modifies the depressant effect of permissive hypercapnia on myocardial contractility in patients with acute respiratory distress syndrome. American Journal of Respiratory and Critical Care Medicine, 162(4), 1361-1365.

WHO, (2016) Tacking drug-resistant infections globally: final report and recommendations.

Submitted: $\quad 16 / 11 / 2020$

Revised: $\quad 28 / 11 / 2020$

Accepted: $\quad 10 / 08 / 2021$

DOI: $\quad 10.48129 / \mathrm{kjs} .11047$ 